\title{
Diagnosis and management of pituitary tumours in the elderly: a review based on personal experience and evidence of literature
}

\author{
Giuseppe Minniti ${ }^{1}$, Vincenzo Esposito ${ }^{1}$, Manolo Piccirilli ${ }^{2}$, Amato Fratticci ${ }^{3}$, Antonio Santoro ${ }^{2}$ and Marie-Lise \\ Jaffrain-Rea ${ }^{1,3}$ \\ ${ }^{1}$ Neuromed IRRCS, Pozzili, ${ }^{2}$ Department of Neurological Sciences, University 'La Sapienza', Rome and ${ }^{3}$ Department of Experimental Medicine, \\ University of L'Aquila, Via Vetoio, Coppito2, 67100 L'Aquila, Italy
}

(Correspondence should be addressed to M-L Jaffrain-Rea at University of L'Aquila, Dipartimento di Medicina Sperimentale; Email: jaffrain.ml@libero.it)

\begin{abstract}
An increasing proportion of pituitary adenomas are recognized in the elderly, raising the question of their optimal diagnosis and management. Age-related endocrine changes and associated diseases may significantly modify the clinical presentation and hormonal evaluation of these patients. About $80 \%$ of pituitary adenomas in this age group are non-secreting, requiring careful differential diagnosis with non-adenomatous sellar lesions. In this group, visual deterioration and hypopituitarism remain the leading symptoms. Recognized secreting tumours are mainly GH-secreting, most of them intrasellar, followed by prolactinomas, which present as clinically non-secreting and are usually invasive. Cushing's disease appears as a very rare eventuality in the elderly. Optimal therapeutic management should aim to control the disease while preserving or improving patient's quality of life. Transsphenoidal surgery has proved to be an efficient and well-tolerated option for non-secreting adenomas with visual defects and intrasellar GH-secreting adenomas, being able to improve metabolic and cardiovascular complications of acromegaly even in this age group. In contrast, dopamine-agonist drugs can be proposed as a primary therapy for prolactinomas even in the presence of severe neurological complications. Because the use of radiotherapy is hampered by its delay of action and potential neurological side effects, its indications should be better defined in this age group. The clinical importance of hypopituitarism should not be underestimated, and thyroid- and adrenal-replacement therapy are mandatory in the presence of documented hormone deficiency, carefully avoiding overtreatment in order to limit possible side effects on the cardiovascular system and bone mineralization. Indications for GH- and sex steroid-replacement therapy still await age-specific guidelines.
\end{abstract}

European Journal of Endocrinology 153 723-735

\section{Introduction}

Pituitary adenomas (PAs) in the elderly, commonly defined as people older than 65 years, represent less than $10 \%$ of all PAs $(1-4)$, but this proportion can reach $15 \%$ for patients with non-functioning PAs (NFPAs) (5) and may currently be underestimated. In fact, because of increasing life expectancy and improving health care of the elderly, diagnosis of PAs in this age group is increasing with time (4). Besides reduced life expectancy, clinical peculiarities of the elderly are represented by age-related changes and associated diseases that may significantly delay the diagnosis of PAs and increase surgical risk. For example, visual-field defects may be missed in patients suffering from common age-related ocular diseases, and clinical manifestations of hypopituitarism can mimick those of ageing. In addition, because NFPAs represent the most common type of PA in this age group $(1,3,4$, $6,7)$, attention should be paid to distinguishing adenomas from other non-secreting lesions of the sellar region. Therapeutic options should also be appropriate for age and, as a general rule, should aim to control the disease while preserving or improving patient's quality of life. To achieve this objective, the relative role of surgery, medical therapy with dopamine-agonist (DA) drugs and somatostatin analogues (SMAs), and radiotherapy needs to be better defined in this age group. Hormone-replacement therapy for hypopituitarism should also be adapted to patient's age.

In this paper we present an updated review of our experience and available literature on this topic (1-11) (see Table 1) in an attempt to better define the safety and efficacy of the different therapeutic 
Table 1 Pituitary adenomas in the elderly: current available literature.

\begin{tabular}{|c|c|c|c|c|c|c|c|}
\hline Study & $\begin{array}{c}\text { Age } \\
\text { (years) }\end{array}$ & $\begin{array}{l}\text { Patient numbers } \\
\text { (M/F; \% of } \\
\text { whole series) }\end{array}$ & Phenotype & Volume & Surgery & Radiotherapy & Other \\
\hline (1) & 70 & $\begin{array}{l}n=22(10 \mathrm{M} / 8 \mathrm{~F} \\
\text { for NFPA; } 9 \%)\end{array}$ & $\begin{array}{l}18 \text { NFPA }(81 \% ; 4 \\
\text { secreting: } 3 \mathrm{GH}, 1 \text { ACTH) }\end{array}$ & $\begin{array}{l}\text { All NFPA Ma } \\
(90 \% \text { SSE) }\end{array}$ & $\begin{array}{l}14 / 18(78 \% ; 12 / 18 \\
\text { NFPA; } 2 / 3 \mathrm{GH}) \text {, all TSS }\end{array}$ & None & $\begin{array}{l}\text { Clinical observation in } \\
\text { non-operated cases }\end{array}$ \\
\hline$(2)$ & 65 & $\begin{array}{l}n=15(2 \mathrm{M} / 13 \mathrm{~F} \\
3.2 \%, \mathrm{GH} \text { only })\end{array}$ & All GH-secreting & $\begin{array}{l}11 \mathrm{Ma} / 4 \mathrm{~m} \\
(33 \% \mathrm{SSE})\end{array}$ & $15 / 15(100 \%)$, all TSS & None & $\begin{array}{l}\text { Pre-operative DAs }(n=9) \\
\text { and/or octreotide }(n=4)\end{array}$ \\
\hline (8) & 60 & $\begin{array}{l}n=48(23 \mathrm{M} / 25 \mathrm{~F} \\
37.5 \%)\end{array}$ & 35 NFPA ( $73 \% ; 13$ secreting) & $43 \mathrm{Ma} / 5 \mathrm{~m}$ & 48/48 (100\%), all TSS & NA & NA \\
\hline (6) & 65 & $n=44(25 \mathrm{M} / 19 \mathrm{~F})$ & $\begin{array}{l}37 \text { NFPA ( } 84 \% \text {; } \\
7 \text { secreting: } 5 \text { GH, } 2 \text { PRL) }\end{array}$ & NA (most Ma) & 38/44 (86\%; 32 TSS, 6 TC) & $\begin{array}{l}\text { Post-operative } \\
(n=14) ; \\
\text { exclusive }(n=2)\end{array}$ & $\begin{array}{l}\text { DA }(n=1) \text {; clinical } \\
\text { observation in } \\
\text { four non-operated } \\
\text { cases }\end{array}$ \\
\hline (3) & 70 & $n=11(5 \mathrm{M} / 6 \mathrm{~F})$ & $\begin{array}{l}8 \text { NFPA }(73 \% \text {; three } \\
\text { secreting: } 1 \mathrm{GH}, 1 \\
\text { PRL, } 1 \text { ACTH) }\end{array}$ & $10 \mathrm{Ma} / 1 \mathrm{~m}$ & $11 / 11(100 \%)$, all TSS & None & NA \\
\hline$(4)$ & 65 & $n=74(45 \mathrm{M} / 39 \mathrm{~F})$ & $\begin{array}{l}52 \mathrm{NFPA}^{*}(70 \% ; 22 \\
\text { secreting: } 11 \mathrm{GH}, 7 \text { PRL, } \\
4 \text { ACTH) }\end{array}$ & $\begin{array}{l}\text { All NFPA Ma } \\
\text { Secreting: } 10 \mathrm{Ma} / 1 \mathrm{~m} \\
\text { (GH); } 7 \mathrm{Ma}(\mathrm{PRL}) ; \\
1 \mathrm{Ma} / 3 \mathrm{~m} \mathrm{(ACTH)}\end{array}$ & $\begin{array}{l}\text { 54/74 (73\%; 44/52 } \\
\text { NFPA*; 10/22 secreting } \\
\text { (6 GH, 2 PRL, } 2 \text { ACTH), } \\
53 \text { TSS, } 1 \text { TC }\end{array}$ & $\begin{array}{l}\text { Post-operative } \\
\text { ( } n=3 \text {, secreting) }\end{array}$ & $\begin{array}{l}\text { Pre-operative DAs in } \\
\text { three PRL-secreting; } \\
\text { clinical observation in all } \\
\text { non-operated cases }\end{array}$ \\
\hline (5) & 70 & $n=32(17 \mathrm{M} / 15 \mathrm{~F})$ & All NFPA & All Ma & $32 / 32(100 \%)$, all TSS & None & None \\
\hline (9) & 65 & $n=22(11 \mathrm{M} / 11 \mathrm{~F})$ & All GH-secreting & $\begin{array}{l}18 \mathrm{Ma} / 4 \mathrm{~m} \\
(36 \% \mathrm{SSE})\end{array}$ & $22 / 22(100 \%)$, all TSS & $\begin{array}{l}\text { Post-operative } \\
\text { in selected cases }\end{array}$ & $\begin{array}{l}\text { Pre-operative somatostatin } \\
\text { analogues }(n=6) \text {, and } \\
\text { post-operative where } \\
\text { indicated }\end{array}$ \\
\hline (7) & 70 & $n=39(21 \mathrm{M} / 18 \mathrm{~F})$ & $\begin{array}{l}31 \text { NFPA ( } 79 \% ; 8 \\
\text { secreting: } 5 \mathrm{GH}, 3 \mathrm{PRL})\end{array}$ & All Ma & 39/39 (100\%), all TSS & $\begin{array}{l}\text { Post-operative } \\
(n=17)\end{array}$ & $\begin{array}{l}\text { Pre-operative DA } \\
\text { ( } n=3 \mathrm{PRL})\end{array}$ \\
\hline
\end{tabular}

*Including seven pituitary apoplexy and one gonadotrophinoma.

ACTH, adrenocorticotrophin; F, female; M, male; m, microadenoma; Ma, macroadenoma; NA, not available; SSE, suprasellar extension; TC, transcranial surgery; TSS, transphenoidal surgery. 
modalities in this peculiar group of patients, and to propose practical guidelines for their management.

\section{Pituitary pathology}

PAs in the elderly are mostly represented by NFPAs; functional adenomas account for about $20 \%$ of all cases with a relative predominance of growth hormone (GH)-secreting tumours (Table 1). In our series of 39 elderly patients who underwent transsphenoidal surgery (TSS) between 1987 and 1997 (7), NFPAs represented $80 \%$ of the whole series, with $\mathrm{GH}-$ and prolactin (PRL)-secreting adenomas accounting for 13 and $7 \%$, respectively. Similar figures have been reported by others, with NFPAs representing $65-84 \%$ of all cases, followed by GH- (9-17\%), PRL- $(4.5-10 \%)$ and adrenocorticotrophin (ACTH)- $(0-6 \%)$ secreting adenomas, respectively $(1,3,4,6,8)$. Noteworthy is that some studies suggest that the incidence of gonadotroph adenomas, usually included in the NFPA group, tends to increase with age and to be more frequently diagnosed above 60 years, especially in men $(12,13)$.

Most PAs in the elderly are slowly growing, and this can be supported by the low rates of cell proliferation commonly reported in this age group (14). An agerelated decrease in cell proliferation has been observed in NFPAs (15) and in GH-secreting tumours (14), the latter being mostly intrasellar in the elderly $(2-4,9)$. ACTH-secreting adenomas associated with Cushing's disease are rare in the elderly, microadenomas being the rule $(3,4)$. On the contrary, prolactinomas are generally diagnosed as macroadenomas $(1,3,4,7)$ and huge tumours are not uncommon, especially in men (16-18), probably because hyperprolactinaemia itself is poorly symptomatic in this age group. In fact, microprolactinomas are the most often recognized at autopsy (19). Spontaneous apoplexy might be favoured by comorbid conditions such as hypertension or anticoagulation (4). However, pituitary apoplexy does not appear to be more frequent in the elderly and remains largely unpredictable, regardless of the patient's age and tumour volume (20).

\section{Clinical presentation}

The clear predominance of NFPAs largely explains the leading symptoms reported in this age group. In fact, clinical presentation is dominated by visual impairment followed by endocrine symptoms (1-9). Visual impairment due to chiasmatic compression occurs in $60-80 \%$ of NFPAs $(1,3,5-8)$ but fewer than $20 \%$ of GH- or ACTH-secreting tumours $(2,4,9)$. Headache is reported in $5-25 \%$ of all patients $(4-7)$ and more frequently in acromegalics (2). Pituitary apoplexy is occasionally reported, especially in NFPAs, reaching $6 \%$ in some series $(1,4)$. Cranial nerve palsy occurs in a small minority of patients, due to either invasion of the cavernous sinus or pituitary apoplexy $(3,4,6)$; ophthalmoplegia may also reveal a pituitary metastasis (21).

Hypopituitarism is variably appreciated as a presenting feature $(0-25 \%)(1,3,4,6)$ and endocrine symptoms of hormone hypersecretion are dominated by acromegaly $(1,4,6,7)$. Where sufficient pre-operative evaluation is available, hypopituitarism has been found in up to $50 \%$ of all cases $(4,6,7)$ and $80 \%$ of NFPAs (5), though limited to gonadotroph deficiency in quite variable proportions. As a rule, hypopituitarism is clinically underestimated in the elderly because typical symptoms are less frequent than in younger patients and overlap with those of ageing $(1,10,22)$. Attention has recently been paid to hyponatremia as a revealing symptom of pituitary diseases in up to $8 \%$ of elderly patients (4, 23). Hyponatremia is favoured by adrenal failure and age-related changes in vasopressin secretion $(23,24)$, and it may be severe and account for aspecific neurological symptoms such as confusion and even coma. Acromegaly or Cushing's disease are recognized on the basis of typical clinical features, although the clinical picture may be milder than in younger patients (10), and associated hypopituitarism is uncommon $(2,9)$. In contrast, systemic complications, such as diabetes mellitus and hypertension, are more frequent in this age group and increase cardiovascular risk $(2,9)$.

Data about prolactinomas in the elderly are limited to small subgroups of PAs including two to seven patients (see Table 1) and single case reports $(16-18,25)$. In men, the clinical picture is quite mixed, but atypical symptoms of hypopituitarism and neurological manifestations are not uncommon $(16-18,25)$. In the last decade (see Table 2), we have observed nine elderly patients with symptomatic prolactinomas (seven women and two men, aged $70.9 \pm 5.3$ years). All had macroadenomas (mean diameter $2.9 \pm 0.9 \mathrm{~cm}$ ), and most of them were invasive. Mean PRL values at diagnosis were highly variable $(725.3 \pm 488 \mathrm{ng} / \mathrm{ml})$, and all patients had partial or complete hypopituitarism $(n=7$ and 2, respectively). In particular, all women had 'menopause'/definitive secondary amenorrhea before the age of 45 (mean $36.0 \pm 10$ years), strongly suggesting a 2030-year period of unrecognized evolution of the disease. The frequently associated osteoporosis also reflects longstanding associated hypogonadism.

Finally, pituitary tumours are increasingly recognized on neuroradiological imaging performed for a comorbid condition, accounting for $5-15 \%$ of patients in this age group $(4,6,7)$. Though most 'pituitary incidentalomas' are asymptomatic, visual or endocrinological changes should be systematically searched for (26).

On the contrary, except for rare cases of pituitary apoplexy, the presence of diabetes insipidus in the setting of a recently recognized pituitary mass indicates the presence of a non-adenomatous lesion, in particular a craniopharyngioma, a lymphocytic hypophysitis or a pituitary metastatasis. 
Table 2 Clinical presentation and evolution of nine elderly patients with prolactinomas.

\begin{tabular}{|c|c|c|c|c|c|c|c|}
\hline Patient & $\begin{array}{l}\text { Age } \\
\text { (years) } \\
\text { and } \\
\text { sex }\end{array}$ & $\begin{array}{c}\text { Symptoms and associated } \\
\text { diseases* }\end{array}$ & Adenoma & Laboratory data $†$ & Medical therapy & Surgery & Follow-up \\
\hline$B G$ & $72, \mathrm{~F}$ & $\begin{array}{l}\text { Headache ( } 3-6 \text { months); } \\
\text { amenorrhea ( } 44 \text { years old); primary } \\
\text { infertility; osteoporosis }\end{array}$ & $\begin{array}{l}\text { Ma- SSE grade A, invasive } \\
\text { (cavernous sinus), max } \\
\text { diam } 2.0 \mathrm{~cm}\end{array}$ & $\begin{array}{l}\mathrm{PRL} 600 \mathrm{ng} / \mathrm{ml} \text {, low } \\
\text { gonadotrophins }\end{array}$ & CAB $1.0 \mathrm{mg} /$ week & No & $\begin{array}{l}5 \text { years, rapid PRL normalization, } \\
\text { progressive tumour shrinkage (up to } \\
50 \% \text { ) }\end{array}$ \\
\hline$C G$ & $74, \mathrm{~F}$ & $\begin{array}{l}\text { Progressive visual defects (2 } \\
\text { years); headache ( } 5 \text { months); post- } \\
\text { partum amenorrhea ( } 38 \text { years old); } \\
\text { osteoporosis }\end{array}$ & $\begin{array}{l}\text { Ma- SSE grade B, invasive } \\
\text { (cavernous sinus and } \\
\text { sphenoid sinus) }\end{array}$ & $\begin{array}{l}\mathrm{PRL} 130 \mathrm{ng} / \mathrm{ml} \text {, } \\
\text { low-normal } \\
\text { gonadotrophins }\end{array}$ & $\begin{array}{l}\text { BRC up to } 7.5 \mathrm{mg} / \text { day for } 6 \\
\text { months, then } C A B 1 \mathrm{mg} / \text { week } \\
\text { for } 2 \text { years, then } 0.5 \text { and } \\
0.25 \mathrm{mg} / \text { week }\end{array}$ & No & $\begin{array}{l}11 \text { years, rapid visual and PRL } \\
\text { normalization, rapid tumour shrinkage } \\
\text { (70\% in } 6 \text { months) then shrinkage up } \\
\text { to } 90 \% \text {, secondary empty sella }\end{array}$ \\
\hline $\mathrm{DGG}$ & $77, \mathrm{~F}$ & $\begin{array}{l}\text { Progressive visual defects ( } 1 \text { year); } \\
\text { neurological symptoms with } \\
\text { memory impairment and recent loss } \\
\text { of autonomy; amenorrhea ( } 45 \text { years } \\
\text { old); hypertension/type } 2 \text { diabetes } \\
\text { mellitus/thyroiditis }\end{array}$ & $\begin{array}{l}\text { Ma- SSE grade A, invasive } \\
\text { (cavernous sinus, } \\
\text { sphenoid sinus, clivus), } \\
\text { Max diam } 3.6 \mathrm{~cm}\end{array}$ & $\begin{array}{l}\mathrm{PRL} 637 \mathrm{ng} / \mathrm{ml} \text {, very } \\
\text { low gonadotrophins }\end{array}$ & $\begin{array}{l}\mathrm{CAB} 1.5 \mathrm{mg} / \text { week, } \mathrm{LT}_{4} \\
75 \mu \mathrm{g} / \text { day }\end{array}$ & $\begin{array}{l}\text { Yes } \\
\text { (TSS) }\end{array}$ & $\begin{array}{l}1 \text { year, PRL } 200 \mathrm{ng} / \mathrm{ml} \text {, post-operative } \\
\text { tumour reduction, progressive } \\
\text { worsening of general and } \\
\text { neurological conditions after acute } \\
\text { myocardial infarction ( } 6 \text { weeks after } \\
\text { TSS) }\end{array}$ \\
\hline DVM & $80, \mathrm{~F}$ & $\begin{array}{l}\text { Progressive visual defects, ongoing } \\
\text { after surgery for bilateral cataract } \\
\text { (2 years); bilateral hemianopsy; } \\
\text { neurological symptoms with } \\
\text { progressive loss of autonomy; } \\
\text { amenorrhea ( } 42 \text { years old); } \\
\text { cardiopathy/Paget's } \\
\text { disease/multinodular goitre }\end{array}$ & $\begin{array}{l}\text { Ma- SSE grade B, non } \\
\text { invasive, max diam } 2.8 \mathrm{~cm}\end{array}$ & $\begin{array}{l}\mathrm{PRL} 1180 \mathrm{ng} / \mathrm{ml} \text {, } \\
\text { complete } \\
\text { hypopituitarism, } \\
\text { hyponatremia } \\
(130 \mathrm{mEq} / \mathrm{l})\end{array}$ & $\begin{array}{l}\mathrm{CAB} 0.5 \mathrm{mg} / \text { week, cortisone } \\
\text { acetate } 25 \mathrm{mg} / \text { day, } \mathrm{LT}_{4} \\
50 \mu \mathrm{g} / \text { day }\end{array}$ & No & $\begin{array}{l}1 \text { year, rapid PRL normalization and } \\
\text { visual improvement, progressive } \\
\text { recovery of functional autonomy and } \\
\text { improvement of adrenal function, } \\
\text { progressive tumour shrinkage (up to } \\
50 \% \text { ) }\end{array}$ \\
\hline DOM & $67, \mathrm{~F}$ & $\begin{array}{l}\text { Progressive visual defects, } \\
\text { bitemporal hemianopsy, amenorrhea } \\
\text { (37 years old), goitre }\end{array}$ & $\begin{array}{l}\text { Ma- SSE grade B/C, } \\
\text { invasive (cavernous sinus), } \\
\text { max diam } 3.0 \mathrm{~cm}\end{array}$ & $\begin{array}{l}\text { PRL } 850 \mathrm{ng} / \mathrm{ml} \text {, low } \\
\text { gonadotrophins }\end{array}$ & $\begin{array}{l}\mathrm{CAB} 1.0 \mathrm{mg} / \text { week, } \mathrm{LT}_{4} \\
75 \mu \mathrm{g} / \text { day }\end{array}$ & No & $\begin{array}{l}3 \text { years, rapid PRL normalization and } \\
\text { visual field defects, progressive } \\
\text { tumour shrinkage (up to nearly } \\
100 \% \text { ), secondary empty sella }\end{array}$ \\
\hline PE & $65, \mathrm{~F}$ & $\begin{array}{l}\text { Headache, amenorrhea (18 years } \\
\text { old), osteoporosis }\end{array}$ & $\begin{array}{l}\text { Ma- no SSE, invasive } \\
\text { (sphenoid sinus), max } \\
\text { diam } 2.0 \mathrm{~cm}\end{array}$ & $\begin{array}{l}\mathrm{PRL} 170 \mathrm{ng} / \mathrm{ml} \text {, low } \\
\text { gonadotrophins }\end{array}$ & $\begin{array}{l}\text { BRC } 2.5 \mathrm{mg} / \mathrm{day} \text { for } 3 \text { months, } \\
\text { then CAB } 0.5 \mathrm{mg} / \text { week }\end{array}$ & $\begin{array}{l}\text { Yes } \\
\text { (TSS) }\end{array}$ & $\begin{array}{l}3 \text { years, rapid normalization of } \mathrm{PRL} \\
\text { and complete regression of the post- } \\
\text { operative remnant, secondary empty } \\
\text { sella }\end{array}$ \\
\hline PAM & $65, \mathrm{~F}$ & $\begin{array}{l}\text { Progressive visual defects ( } 7 \text { years; } \\
\text { unilateral temporal), amenorrhea ( } 30 \\
\text { years old), hypertension/osteoporosis }\end{array}$ & $\begin{array}{l}\text { Ma- SSE grade } A / B \text {, } \\
\text { invasive, max diam } 3.5 \mathrm{~cm}\end{array}$ & $\begin{array}{l}\mathrm{PRL} 550 \mathrm{ng} / \mathrm{ml} \text {, } \\
\text { complete } \\
\text { hypopituitarism }\end{array}$ & $\begin{array}{l}\text { BRC up to } 20 \mathrm{mg} / \mathrm{day} \text {, } \\
\text { cortisone acetate } 25 \mathrm{mg} / \text { day, } \\
\mathrm{LT}_{4} 82.5 \mu \mathrm{g} / \text { day }\end{array}$ & $\begin{array}{c}\text { Yes } \\
\text { (TSS) }\end{array}$ & $\begin{array}{l}8 \text { years, progressive PRL } \\
\text { normalization and visual } \\
\text { improvement, progressive shrinkage } \\
\text { of post-operative remnant (up to } \\
80 \%) \text {, secondary empty sella }\end{array}$ \\
\hline SS & $69, \mathrm{M}$ & $\begin{array}{l}\text { Acute cerebral ischaemia, } \\
\text { progressive visual defects (bitemporal } \\
\text { hemianopsy), hypertension }\end{array}$ & $\begin{array}{l}\text { Giant, SSE grade B, } \\
\text { invasive (sphenoid sinus, } \\
\text { clivus), max diam } 5.0 \mathrm{~cm}\end{array}$ & $\begin{array}{l}\mathrm{PRL} 702 \mathrm{ng} / \mathrm{ml} \text {, } \\
\text { hypogonadism }\end{array}$ & $\mathrm{CAB}$ up to $3.5 \mathrm{mg} /$ week & $\begin{array}{l}\text { Yes } \\
\text { (TSS) }\end{array}$ & $\begin{array}{l}7 \text { years, visual improvement despite } \\
\text { partial pharmacological resistance, } \\
\text { stabilization of post-operative pituitary } \\
\text { mass with cystic evolution and slowly } \\
\text { progressive PRL normalization }\end{array}$ \\
\hline SGC & $69, \mathrm{M}$ & $\begin{array}{l}\text { Visual defects, optic neuritis/benign } \\
\text { prostatic hypertrophy/osteoporosis }\end{array}$ & $\begin{array}{l}\text { Ma- SSE grade A, not } \\
\text { clearly invasive, max diam } \\
2.0 \mathrm{~cm}\end{array}$ & $\begin{array}{l}\text { PRL } 1709 \mathrm{ng} / \mathrm{ml} \text {, } \\
\text { hypogonadism }\end{array}$ & CAB 0.5 & No & $\begin{array}{l}2 \text { years, rapid } P R L \text { normalization, no } \\
\text { significant tumour shrinkage }\end{array}$ \\
\hline
\end{tabular}

* Revealing symptoms are in bold, associated diseases are in italics.

HFor women, normal post-menopausal ranges were considered.
BRC, bromocriptine; CAB, cabergoline; F, female; M, male; Ma-, macroadenoma; SSE, suprasellar extension; $\mathrm{LT}_{4}$, L-thyroxine. 


\section{Diagnosis}

The diagnosis of pituitary tumours relies on neuroradiological imaging - essentially magnetic resonance imaging - and endocrine assessment of pituitary function. Despite many diagnostic criteria being independent of age in adults, possible pitfalls should be kept in mind in the elderly.

\section{Neuroradiological diagnosis}

With the exception of Cushing's disease, in which evidence for a well-defined pituitary lesion may be lacking, the diagnosis of PAs is generally easy in patients with a documented syndrome of hormone hypersecretion. In contrast, an effort must be made to distinguish NFPAs from other non-secreting sellar lesions, since this can radically change therapeutic options, in particular surgical indications and approach. Although data concerning the prevalence of the different sellar lesions in the elderly are lacking, Turner et al. (4) observed 10 patients with a non-adenomatous lesion out of a series of 67 , including chordoma, lymphocytic hypophysitis, carotid aneurysm, metastasis, craniopharyngioma and meningioma. Details concerning clinical anamnesis and symptoms may greatly help to achieve a correct neuroradiological diagnosis (27).

\section{Peculiarity of bioclinical endocrine changes in the elderly}

Ageing is associated with a number of endocrine and metabolic changes changes, including significant changes in the hypothalamo-pituitary axis and related peripheral endocrine glands (28). The anterior pituitary gland itself undergoes morphological changes in the ageing man, including fibrosis and vascular alterations, and a number of abnormalities of pituitary function, though somewhat contradictory, have been reported in the elderly (for a review see (29)). However, progressive $\mathrm{GH}$ deficiency, post-menopausal changes in women, age-related androgen decline in men (30) and the more recently characterized age-related changes in adrenal secretion (31) should be held in mind when interpreting endocrine parameters. In addition, due to frequent comorbid conditions, a number of drug-induced hormonal abnormalities can be encountered in this age group.

The diagnosis of some pituitary hypersecretory states should be adapted to a patient's age and medical conditions. If basal PRL secretion itself is not consistently modified with age $(10,29)$ it can be influenced by a number of drugs leading to moderate hyperprolactinaemia or be markedly suppressed by DAs prescribed for extrapyramidal disorders, thereby masking hyperprolactinaemia. It may therefore be excessively difficult to recognize a prolactinoma in such patients. In addition, if moderate hyperprolactinaemia is frequent in patients with non-secreting lesions because of pituitary stalk compression, it is advisable in patients with huge tumours to dilute plasma samples in order not to miss very high PRL concentrations, which may give rise to erroneously low values in two-site 'sandwich' assays (the so-called hook effect) (32).

In patients with suspected acromegaly, age-corrected insulin-like growth factor I (IGF-I) ranges must be considered because of the marked decline in IGF-I secretion (normal values are less than $220 \mathrm{ng} / \mathrm{ml}$ in most assays). Since overt diabetes mellitus may limit the feasibility or reliability of the oral glucose-tolerance test for $\mathrm{GH}$ suppression, alternative testing such as thyrotrophin-releasing hormone stimulation may be indicated. There is also recent evidence than a 3-h GH profile may give results similar to oral glucose-tolerance test in acromegalics (33).

As far as gonadotroph adenomas are concerned, they generally present as NFPAs and, since their treatment is mostly the same at the moment, their pre-operative diagnosis may not be considered as essential in clinical practice. However, up to $40-50 \%$ of gonadotroph adenomas can be simply recognized in men on the basis of elevated follicle-stimulating hormone or luteinizing hormone (LH) levels $(12,13)$. Determination of $\alpha$ - and $\beta$-follicle-stimulating hormone, and $\beta \mathrm{LH}$, especially after thyrotrophin-releasing hormone stimulation, may increase the diagnostic sensitivity up to $70 \%$ in male and $50 \%$ in female patients, respectively, although this cannot be routinely proposed (12).

Finally, in patients with suspected ACTH-secreting adenomas, attention should be paid to dementia and depression, which are frequently accompanied by abnormalities of cortisol secretion $(10,29)$. A relative decrease in the hypothalamic-pituitary sensitivity to glucocorticoid feedback may also be encountered in the elderly or during chronic illness (29), so that current criteria using $1.8 \mu \mathrm{g} / \mathrm{dl}$ as a threshold for plasma cortisol suppression after low-dose dexamethasone-suppression test (34) might be too restrictive in elderly patients. Further studies would be necessary to clarify this point.

Another essential aspect of pituitary tumours is hypopituitarism, which should be recognized because of its impact on life quality and surgical risk. Classically, acquired hypopituitarism progressively involves different pituitary functions: GH deficiency appears first, followed by hypogonadotrophic hypogonadism and, at a later stage, secondary adrenal and/or thyroid insufficiency may develop.

GH deficiency in the elderly may not be easily distinguished from the age-related decrease in spontaneous GH secretion (the so-called somatopause), especially when partial GH deficiency is searched for. Revising data dealing with abnormalities of $\mathrm{GH}$ testing in the ageing population falls beyond the scope of the present review. However, current available data indicate that combined stimulation with GH-releasing hormone + arginine, which represents a safe and reliable test for the evaluation of the GH secretory capacity even in the 
elderly (35), may be the test of choice in these patients when accurate diagnosis of GH deficiency is thought necessary. Alternatively, combined stimulation with GH-releasing hormone + GHRP6 may be proposed (36).

Similarly, androgen deficiency in elderly men may not be of univocal interpretation, and an effort should be made to distinguish true hypogonadotropic hypogonadism from the progressive age-related decline in androgen levels currently described as PADAM (partial androgen deficiency of the aging male). According to a recent review (29), blood testosterone determination remains the best marker of androgen status and thresholds of $315 \mathrm{ng} / \mathrm{dl}$ for total testosterone and $6.5 \mathrm{ng} / \mathrm{dl}$ for free testosterone can be proposed. About 20\% of men above 60 years have low plasma androgen levels, mainly due to alterations in testicular production and LH dysregulation, with a modest and inconstant increases in LH levels. Thus a simultaneous decrease of plasma testosterone and gonadotrophins, if present, still argues for hypogonadotrophic hypogonadism in the elderly, though normal gonadotrophins do not exclude this eventuality, especially in patients with pituitary tumours. In fact, it should be remembered that most gonadotroph adenomas are associated with low plasma androgens, regardless of gonadotrophin levels (12). Finally, a number of associated acute and chronic diseases and drugs are known to negatively influence androgen status (29). It is therefore reasonable, in most cases, to repeat testosterone determination more than once to confirm hypogonadism.

Although secondary thyroid or adrenal insufficiency are less common than GH deficiency or hypogonadotrophic hypogonadism, they should be best recognized because of their immediate implications for hormonereplacement therapy. In the presence of inadequately low to normal thyroid-stimulating hormone values, low plasma free thyroxine $\left(\mathrm{FT}_{4}\right)$ values are the best marker of central hypothyroidism (37), whereas free triiodothyronine $\left(\mathrm{FT}_{3}\right)$ is the first to decrease in non-thyroidal illness syndrome, a common condition in acute situations or in hospitalized patients (38). Noteworthy is that associated thyroid diseases are more common in the elderly (39). Low basal or ACTH-stimulated morning plasma cortisol are the most simple and suitable indices of secondary adrenal insufficiency, though their sensitivity may be insufficient (40), so that clinical evaluation remains important for further therapeutic decision. Importantly, cortisol secretion is not reduced by adrenopause, which is characterized mainly by an age-related reduction in dehydroepiandrostenedione (DHEAS) production (41).

\section{Therapeutic management}

\section{Surgery}

Data summarizing results of TSS obtained in elderly patients are presented in Table 3. TSS is generally safe and successful in elderly patients and can be proposed after evaluation of anaesthesiological risk by using the ASA grading (42), excluding patients with ASA 4 or 5 because of excessive surgical risk. Despite an increased anaesthesiological risk in more than $70 \%$ of patients due to the presence of mild or severe associated diseases $(2,5,7,9)$, no mortality or major complications were observed in recent series of elderly patients operated on by TSS $(2-5,7,9)$, markedly contrasting with their frequency after craniotomy (6). The incidence of post-operative complications is variably appreciated in this age group, the most frequent being diabetes insipidus (transient in 10-50\%, definitive in less than 10\%) and cerebrospinal fluid leak $(0-27 \%)(2-5,7-9)$, which seems higher than usually reported after TSS (43). Whether this is due to ageing itself or to the predominance of large NFPAs is unclear. Anyway, as recently pointed out in a very large series, old patients benefit most from the surgeon's experience (44), reinforcing the importance of dedicated pituitary surgeons in such patients. The development of endoscopic techniques may further reduce surgical risk (45).

Once the diagnosis of prolactinoma is excluded (6), TSS represents the treatment of choice for elderly patients presenting with visual disturbances. Post-operative visual improvement has been consistently reported in more than $70 \%$ of patients $(3-7)$, despite a small percentage of further visual deterioration due to haemorrhagic or ischaemic damage $(1,4)$. In contrast, TSS has been rarely associated with improved pituitary function $(5,7,9)$, suggesting that recovery of pre-operative hypopituitarism in the elderly is less frequent than in younger patients (46). Conflicting results have been reported about post-operative regrowth of NFPAs in patients treated by surgery alone (47-49) and there are very few data in elderly patients (see Table 3). In our experience, only $16 \%$ of non-irradiated elderly patients with total or subtotal removal of NFPAs recurred during follow-up (7). Postoperative regrowth was also found to be less frequent in the elderly than in younger patients (50). This suggests that TSS alone can be considered for patients with a satisfactory tumour removal, provided that a regular neuroradiological imaging is planned.

Surgical indications for non-secreting sellar lesions in the absence of visual impairment are still debated. In patients with NFPAs, regular follow-up can be recommended on the basis of their commonly slow growing potential, and this can apply to most pituitary intrasellar incidentalomas (26), keeping in mind that about $25 \%$ of asymptomatic macroadenomas may increase in size over 5 years (51) - a few similar data-sets are available in the elderly (4). In such cases, surgery can be avoided unless magnetic resonance imaging shows a progressive growth of adenoma in the suprasellar space threatening the optic chiasm. For asymptomatic patients with extrasellar lesions, 


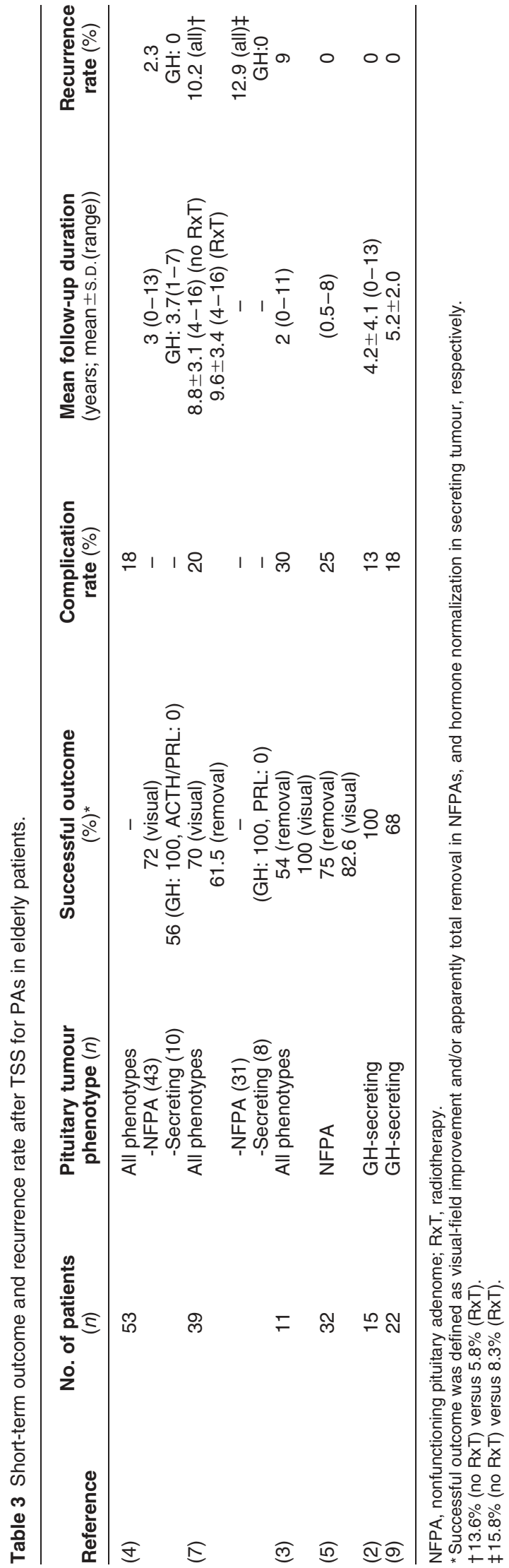

TSS may be recommended to prevent further complications of the disease, depending on the clinical status of the patient.

Surgery is considered by most authors as the first therapeutic choice in acromegaly, TSS being able to achieve biochemical remission of acromegaly in $50-60 \%$ of patients according to strict criteria of cure; that is, normal age-corrected IGF-I levels and glucose-suppressed GH levels lower than $1 \mathrm{ng} / \mathrm{ml}$ (52). Current data on TSS in elderly acromegalics are encouraging. We have recently reported surgical outcome in 22 elderly acromegalics (9): despite the high incidence of hypertension, left ventricular hypertrophy and glucose metabolism abnormalities, no major complications occurred and GH/IGF-I normalization was achieved in $68 \%$ of patients. While doubtful recurrences could be observed in a previous study using basal $\mathrm{GH}<4.5 \mathrm{ng} / \mathrm{ml}$ and IGF-I $<380 \mathrm{ng} / \mathrm{ml}$ as successful outcome criteria (2), we did not observe any recurrence during a median follow-up of 5 years where strict criteria of cure were met. Noteworthy, successful TSS was accompanied by a significant improvement in cardiovascular and metabolic abnormalities (9). It is likely that the satisfactory surgical outcome was favoured by the intrasellar location of the adenoma in most cases. Pre-operative treatment with SMAs may be useful to improve patient's conditions, especially from a cardiorespiratory point of view; it may reduce anaesthetic difficulties $(53,54)$ and shorten the duration of hospitalization (55). The indications of SMAs in elderly acromegalics will be further discussed below.

TSS also appears as a first choice treatment in elderly patients with Cushing's disease, since it is poorly responsive to medical treatment, whereas TSS is successful in $70-90 \%$ of the cases. Despite the variable surgical outcome reported in a small number of elderly patients $(3,4)$, young patients were found to be the most at risk group for recurrence in a large multicentre study including patients up to 84 years of age (56). Thus further experience is necessary to better define surgical outcome in this age group.

In contrast, most authors agree to consider surgery as a second choice of treatment for patients with prolactinoma at any age, when DAs prove to be inefficient or badly tolerated, even though some advocate TSS for microprolactinomas when conditions for definitive cure are fulfilled (57). However, surgery for microprolactinomas would be highly questionable in the elderly, since hyperprolactinaemia itself is poorly symptomatic. On the other hand, macroprolactinomas are poorly controlled by TSS (57), and this seems to be especially true in the elderly $(4,6,7)$. We have thus progressively abandoned TSS as a debulking option in these patients, and further limited surgical indications to resistant macroprolactinomas with visual defects or clear radiological evidence of tumour progression. 


\section{Medical therapy}

The development of new therapeutic agents has dramatically increased the opportunity for successful medical therapy for secreting PAs over the last two decades. On the other hand, adequate treatment of hypopituitarism is necessary to improve patients' conditions and quality of life.

\section{Medical treatment of prolactinomas}

DAs represent the first option in the treatment of prolactinomas, being able to normalize PRL levels and induce tumour shrinkage in approximately $70-80 \%$ of cases (58). However, previous data have suggested that prolactinomas in the elderly may be more frequently resistant (4). In addition, among the potential side effects of DAs, dizziness and postural hypotension may be of special concern in the elderly, though cabergoline $(\mathrm{CAB})$ is better tolerated and more efficient than bromocriptine (BRC), making it a suitable first-line option in this age group. In our experience with a series of nine elderly patients (see Table 2), one developed rapid and recurrent weight loss on BRC therapy (patient CG, Table 2) and another suffered from nausea and dizziness, limiting the required increase in CAB dose (patient DGG, Table 2); in the remaining patients, starting with $0.125-0.25 \mathrm{mg}$ twice weekly with recommendations on drug intake, the tolerance to $\mathrm{CAB}$ was excellent. Follow-up duration ranged from 1 to 10 years (mean $4.6 \pm 3.5$ years). Two patients showed partial resistance to DA therapy, requiring high doses of BRC and CAB (patients PAM and SS, Table 2). In the remaining cases, the mean weekly dose required to normalize PRL levels was $0.8 \pm 0.3 \mathrm{mg}$. Tumour shrinkage ranging from 50 to $100 \%$ could be achieved in six out of eight patients who normalized PRL levels, including the patient requiring high BRC treatment dose (patient PAM, Table 2), whereas in the patient requiring a high $\mathrm{CAB}$ dose a cystic evolution was observed. These findings tend to confirm previous observations in men that DA sensitivity is independent from age (25). Noteworthy, a good response has been documented, even in massive prolactinomas inducing hydrocephalus or a confusional state in this age group (16-18).

A still unresolved issue is the need for systematic pharmacological treatment of hyperprolactinaemia in post-menopausal women. In a recent retrospective study (59), 45\% of hyperprolactinaemic women who had passed though the menopause normalized their PRL levels, indicating that post-menopausal women who were already on pharmacological therapy at the time of ovarian failure should be re-evaluated. On the other hand, as pointed out above, symptomatic prolactinomas in post-menopausal women are usually macroprolactinomas that require pharmacological therapy because of mass effects. Thus, microprolactinomas could be recognized mostly as 'incidentalomas', raising the question of the possible benefits of active treatment, if any. As a rule, microprolactinomas are rarely evolutive and, to our knowledge, there is no current evidence for increased bone demineralization in hyperprolactinaemic versus normoprolactinaemic post-menopausal women. Thus, a wait-and-see option seems reasonable in most cases, although dedicated longitudinal studies would be necessary to clarify this point.

\section{Medical therapy for acromegaly}

The long-acting SMAs octreotide-LAR and lanreotide are able to normalize GH/IGF-I levels in $60-70 \%$ of acromegalic patients with acceptable side effects and a significant improvement in disease-related cardiovascular abnormalities (60-62), with partial tumour shrinkage being reported in $30-50 \%$ of patients (62). Elderly acromegalics may be especially sensitive to SMAs (63), though this might be biased by the less aggressive characteristics of GH-secreting adenomas in this age group. Medical therapy implies life-long treatment with a high sanitary cost, which has recently been estimated to range from 6000 to $10000 € /$ patient per year in Italy (64). Another drawback of SMAs is suppression of insulin secretion, which may have further deleterious effects on age- and disease-related abnormalities of glucose metabolism, though both improving and worsening effects can be observed due to the beneficial effects of GH normalization on insulin tolerance (65). However, pharmacological treatment with SMAs can be proposed in different ways. Though pre-operative treatment with SMAs has not been consistently shown to improve surgical outcome, it can significantly reduce anaesthetic complications (54) which is of special concern in the elderly. Upper airway obstruction favouring sleep apnea and difficulties of intubation can be significantly reversed by SMAs within 6 months of treatment (54). Left ventricular hypertrophy, cardiac performance and the frequency of potentially life-threatening arrythmias can significantly improve throughout a similar period of time and even more rapidly $(60,61,66)$. In clinical practice, we propose SMAs as a pre-operative therapy for a 3-6-month period in elderly patients with disease-related cardiorespiratory complications, individually verifying the adequacy of treatment schedule and duration before surgery, and as a long-term treatment in the presence of unacceptable surgical risks, invalidating or life-threatening associated conditions, or postoperative ongoing GH/IGF-I hypersecretion. First-line medical treatment can also be proposed for large GH-secreting adenomas, since surgery alone is rarely able to normalize GH/IGF-I hypersecretion. In such cases, however, surgical debulking of the tumour can still improve hormonal control by SMAs (67). Other medical options in acromegaly are represented by DAs, especially for GH-/PRL-secreting adenomas, and 
the more recently introduced GH antagonist pegvisomant (68). Treating acromegaly with DAs requires higher doses than those commonly employed for prolactinomas and normalization of GH/IGF-I levels is achieved in $30 \%$ of patients only (62). To our knowledge, there are no age-related peculiarities in the use of pegvisomant, which is currently reserved for otherwise uncontrolled acromegaly.

\section{Medical therapy for Cushing's disease}

There are few data about medical treatment of elderly patients with Cushing's disease. Though new promising options are being proposed (69), medical therapy directed to ACTH-secreting adenomas have long been disappointing and control of hypercortisolism can still be best achieved with drugs acting directly on the adrenal glands, such as ketoconazole. Thus surgery or radiotherapy remain the preferred therapeutic options, even in the elderly.

\section{Medical treatment of clinically non-secreting PAs}

So far, no medical treatment has proved to be effective in the control of NFPAs. However, a mild and inconstant shrinkage has been observed in a minority of cases with the use of DAs (70), SMAs (71) or both (72). Since DAs are generally well-tolerated and have a low sanitary cost, randomized trials on their longterm use in uncomplicated macro-NFPAs could be proposed. At the moment, there is no recognized indication for any primary medical option in the treatment of NFPAs.

\section{Treatment of hypopituitarism}

The impact of hypopituitarism on life quality should be considered in elderly as well as in younger patients. However, age-related changes and associated pathological conditions should be individually evaluated to determine optimal indications and modalities of hormone-replacement therapy. Of particular importance are abnormalities of glucose metabolism, cardiovascular diseases, bone demineralization and the eventuality of endocrine-dependent cancer.

Basic medical treatment of hypopituitarism in the elderly relies on thyroid- and adrenal-replacement therapy, which is mandatory in all documented cases. There is no counter-indications to thyroid- or adrenal-replacement therapy in the elderly, provided that overtreatment is avoided because of the potential adverse effects of both hormones on the cardiovascular system and bone metabolism (73). L-Thyroxine is the treatment of choice for central hypothyroidism and should be preceded by adequate adrenal replacement. We generally use a starting dose of $25 \mu \mathrm{g} /$ day of L-thyroxine with a progressive increase to
$1.3 \pm 0.2 \mu \mathrm{g} / \mathrm{kg}$ per day, which has been found optimal in patients older than 60 years (37). Clinical parameters and both plasma $\mathrm{FT}_{3}$ and $\mathrm{FT}_{4}$ concentrations should be used for treatment monitoring, since low thyroid-stimulating hormone levels in such patients are not indicative of overtreatment, which may be best recognized by $\mathrm{FT}_{3}$ measurement in some cases (37). To our knowledge, in the absence of age-related recommendations concerning adrenal replacement in the elderly, it is reasonable to use the lowest daily dose able to correct clinical symptoms such as asthenia and hypotension and maintain serum electrolytes in the normal range (in our experience a $25 \mathrm{mg}$ daily dose of cortisone acetate is sufficient in most cases; see Table 2). Pre-operative treatment of adrenal and thyroid failure are advisable before surgery if indicated.

Replacement therapy with sex steroids should be considered with caution in the elderly, because of its potential cardiovascular side effects and increase in steroid-dependent cancer risk. In women, oestrogenreplacement therapy is generally no longer considered in this age group, since most authors agree to recommend it for a limited period after menopause (74). In men, stable levels of plasma testosterone in the low normal range can be best achieved by transdermal preparations, which avoid the supraphysiological peaks following intramuscular injections. Because the benefits and safety of androgens are still unclear in this age group, only patients with symptomatic hypogonadism, testosterone levels less than $200 \mathrm{ng} / \mathrm{dl}$ and no evidence of absolute contraindications are currently proposed as candidates for this treatment, with regular determination of prostate specific antigen (PSA) and red cell blood count $(75,76)$.

GH-replacement therapy has also been proposed to elderly hypopituitary patients. Recent data from KIMS show beneficial effects almost similar to those seen in younger patients; however, adverse side effects were more frequent than in younger patients (77) and lower doses of GH may be required (78). Thus, indications and dose regimen of $\mathrm{GH}$ replacement in this age group still need to be better defined. In addition, the close relationship between the IGF system, cell proliferation and cancer, and epidemiological evidence that increased circulating IGF-I levels are associated with an increased risk for the development of several common malignant neoplasia (79), should be kept in mind. Of note, these include breast and prostate cancer, so that combined replacement therapy with sex steroids and $\mathrm{GH}$ should be proposed with special caution. Recently, a synergic effect of testosterone and GH-replacement therapy on prostate volume has been documented after only 12 months of treatment in adult hypopituitary patients, including an elderly subgroup, strongly indicating that a longer follow-up is required to look for the possible development of prostate abnormalities (80). 


\section{Radiotherapy}

Conventional fractionated radiotherapy is frequently administered to patients with residual or recurrent pituitary disease. Control of tumour growth is achieved in approximately $90 \%$ of PAs and associated with hormonal control in 40-60\% in secreting tumours. The most common late morbidity of conventional radiotherapy is hypopituitarism, with an overall risk of $40-80 \%$ at 10 years $(81-83)$. Rare complications include optic neuropathy, variable degrees of radionecrosis and late neurocognitive functions, with a reported incidence of $1-3 \%(81-84)$. An increased risk of cerebrovascular mortality compared with the general population has been reported in patients with PAs treated with surgery and radiotherapy $(84,85)$. Possible risk factors include hypopituitarism, radiotherapy and extent of surgery, but none are at present proven causes.

No consensus guidelines are available about the use of radiation therapy in elderly patients with PAs, but limited experience indicates that conventional radiotherapy is feasible in this age group. Though it has been proposed as an alternative to surgery in selected cases $(6,11)$, it is generally viewed as a post-operative treatment, which reduces the recurrence rate in the elderly too (Table 3). Considering the low incidence of recurrences following total or subtotal tumour resection and the shorter expectancy of life in such patients, it is reasonable to propose that radiotherapy should not be planned for grossly resected NFPAs unless regrowth can be documented by radiological follow-up, while it may be considered in patients with large post-operative residual tumour abutting the optic chiasm. In elderly patients with secreting adenomas, the efficacy of conventional radiotherapy is hampered by the interval required to achieve biochemical remission: GH/IGF-I levels reach normal values in about $50 \%$ of acromegalics over a period of $10-15$ years $(82,83)$ and most patients irradiated for Cushing's disease show remission within $4-5$ years (86). Prolactinomas are generally reported to be less sensitive to radiotherapy, but experience is relatively scarce because of its limited indications. Thus, medical therapy is advisable for elderly patients with post-operative remnants of $\mathrm{GH}$ or PRL-secreting tumours to achieve a rapid normalization of hormonal hypersecretion, whereas radiotherapy remains an important option in those unresponsive to medical treatment.

Single-dose stereotactic techniques using either a gamma knife or a modified linear accelerator, also known as radiosurgery, have been developed to achieve high disease control rates while minimizing the risk to the central nervous system. Because of the damaging effects of single high-radiation doses, radiosurgery is only suitable for small lesions at least $5 \mathrm{~mm}$ away from the optic chiasm. Early results are encouraging: hormone normalization has been reported in about $40-50 \%$ of GH-secreting, up to $60 \%$ of ACTH-secreting and $30 \%$ of PRL-secreting adenomas, with a time to hormonal response ranging from 6 months to 4 years, whereas the reported control rate for NFPAs exceeds $90 \%$, with a low incidence of side effects (87). Although more long follow-up periods are needed, it is likely that radiosurgery can partially overcome the limits due to the slow effects of conventional irradiation.

Another promising approach is stereotactic conformal radiotherapy, which combines the precision of stereotactic techniques with the fractionation of conventional techniques (88). Though longer follow-up periods are also necessary to better assess its efficacy and toxicity (87), it may be especially attractive for use in the elderly.

\section{Conclusion}

An increasing proportion of PAs are being recognized in the elderly, raising the question of their optimal management. Evidence from literature emphasizes the importance of TSS in elderly patients affected by NFPAs with visual disturbance or intrasellar GH-secreting adenomas. On the contrary, medical treatment with DA is the first-line treatment for prolactinomas, regardless of their volume and the presence of neurological symptoms. SMAs are useful in acromegalic patients with large tumours, with a high anaesthesiological risk or with a post-operative active disease. Although radiotherapy can play an important role in the control of tumour regrowth and hormonal hypersecretion, its indications and modalities in the elderly should be better defined. The clinical importance of hypopituitarism should not be underestimated, and thyroid- and adrenal-replacement therapy are mandatory in the presence of documented hormone deficiency, carefully avoiding overtreatment to limit possible side effects on the cardiovascular system and bone mineralization.

\section{References}

1 Cohen DL, Bevan JS \& Adams CBT. The presentation and management of pituitary tumours in the elderly. Age Ageing 198918 247-252.

2 Puchner MJA, Knappe UJ \& Ludecke DK. Pituitary surgery in elderly patients with acromegaly. Neurosurgery $19953 \mathbf{3 6}$ 677-684.

3 Fraioli B, Pastore FS, Signoretti S, De Caro GMF \& Giuffrè R. The surgical treatment of pituitary adenomas in the eigth decade. Surgical Neurology $199951261-267$.

4 Turner HE, Adams CBT \& Wass JAH. Pituitary tumours in the elderly: a 20-year experience. European Journal of Endocrinology $1999140383-389$.

5 Kurosaki M, Ludecke DK, Flitsch J \& Saeger W. Surgical treatment of clinically non-secreting pituitary adenomas in elderly patients. Neurosurgery $2000 \mathbf{4 7} 843-849$.

6 Benbow SJ, Foy P, Jones B, Shaw D \& McFarlane IA. Pituitary tumours presenting in the elderly: management and outcome. Clinical Endocrinology (Oxford) 199746 657-660. 
7 Ferrante L, Trillo G, Ramundo E, Celli P, Jaffrain-Rea ML, Salvati M, Esposito V, Roperto R, Osti MF \& Minniti G. Surgical treatment of pituitary tumors in the elderly: clinical outcome and long-term follow-up. Journal of Neuro-Oncology $2002 \mathbf{6 0}$ 185-191.

8 Pospiech J, Stolke D \& Pospiech FR. Surgical treatment of pituitary adenomas in the elderly. Acta Neurochirurgica Supplement (Wien) $19966535-36$.

9 Minniti G, Jaffrain-Rea ML, Esposito V, Santoro A, Moroni C, Lenzi J, Tamburrano G, Cassone R \& Cantore G. Surgical treatment and clinical outcome of GH-secreting adenomas in elderly patients. Acta Neurochirurgica (Wien) $20011431205-1211$.

10 Turner HE \& Wass JAH. Pituitary tumours in the elderly. Baillière's Clinical Endocrinology \& Metabolism 199711 407-422.

11 Losa M. Pituitary tumors in the elderly. European Journal of Endocrinology $1999140378-380$.

12 Young WF Jr, Scheithauer BW, Kovacs KT, Horvath E, Davis DH \& Randall RV. Gonadotroph adenoma of the pituitary gland: a clinicopathologic analysis of 100 cases. Mayo Clinic Proceedings 1996 $71649-656$.

13 Ho MD, Hsu CY, Ting LT \& Chiang H. The clinicopathological characteristics of gonadotroph cell adenoma: a study of 118 cases. Human Pathology 199728 905-911.

14 Jaffrain-Rea ML, Di Stefano D, Minniti G, Esposito V, Bultrini A, Ferretti E, Santoro A, Faticanti Scucchi L, Gulino A \& Cantore G. A critical reappraisal of MIB-1 labelling index significance in a large series of pituitary tumours: secreting versus non-secreting adenomas. Endocrine-Related Cancer 20029 $103-113$.

15 Losa M, Franzin A, Mangili F, Terreni MR, Barzaghi R, Veglia F, Mortini P \& Giovanelli M. Proliferation index in non-functioning pituitary adenomas: clinical characteristics and long-term followup. Neurosurgery 200047 1313-1318.

16 Zikel OM, Atkinson JLD \& Hurley DL. Prolactinoma manifesting with symptomatic hydrocephalus. Mayo Clinic Proceedings 1999 74 475-477.

17 Saeed S, Farooqi OA, Panayiotou B \& Harvey TC. Reversible confusional state in an elderly man. Postgraduate Medical Journal $199975365-366$.

18 Iglesias P, Macho LP \& Diez JJ. Resolution of macroprolactinomainduced symptomatic hydrocephalus following cabergoline therapy. Age Ageing 200433 410-412.

19 Kovacs K, Ryan N, Horvath E, Singer W \& Ezrin C. Pituitary adenomas in old age. Journal of Gerontology 198035 16-22.

20 Biousse V, Newman NJ \& Oyesiku NM. Precipitating factors in pituitary apoplexy. Journal of Neurology Neurosurgery and Psychiatry $200171542-545$.

21 Komninos J, Vlassopoulou V, Protopapa D, Korfias S, Kontogeorgos G, Sakas DE \& Thalassinos NC. Tumors metastatic to the pituitary gland: case report and literature review. Journal of Clinical Endocrinology and Metabolism 2004 89 574-580.

22 Tayal SC, Bansal SK \& Chadha DK. Hypopituitarism: a difficult diagnosis in elderly people but worth a search. Age Ageing 1994 23 320-322.

23 Diederich S, Franzen NF, Bahr V \& Oelkers W. Severe hyponatremia due to hypopituitarism with adrenal insufficiency: report on 28 cases. Journal of Endocrinology 2003148 609-617.

24 Chanson P. Severe hyponatremia as a frequent revealing sign of hypopituitarism after 60 years of age. European Journal of Endocrinology $2003 \mathbf{1 4 9} 177-188$.

25 Delgrange E, Maiter D, Donckier J \& Tourniaire J. Influence of age on the clinical presentation of prolactinomas in male patients. Gerontology $1999 \mathbf{4 5} 160-164$.

26 Molitch ME. Evaluation and treatment of the patient with a pituitary incidentaloma. Journal of Clinical Endocrinology and Metabolism $1995 \mathbf{8 0} 3-6$.

27 Armstrong $\mathrm{P} \&$ Charlesworth M. Imaging of the pituitary and hypothalamus. In Clinical Endocrine Oncology, pp 158-167. Eds R Sheaves, PJ Jenkins \& JA Wass. Oxford: Blackwell Science, 1997.
28 Lamberts SWJ, van den Beld AW \& van der Lely AJ. The endocrinology of aging. Science 1997278 419-424.

29 Blackman MR. Pituitary hormones and aging. Endocrinology and Metabolism Clinics $198716981-994$.

30 Kaufman JM \& Vermeulen A. The decline of androgen levels in elderly men and its clinical and therapeutic implications. Endocrine Reviews $200526833-876$.

31 Ferrari E, Cravello L, Muzzoni B, Casarotti D, Paltro M, Solerte SB, Fioravanti M, Cuzzoni G, Pontiggia B \& Magri F. Age-related changes of the hypothalamic-pituitary-adrenal axis: pathophysiological correlates. European Journal of Endocrinology $2001 \mathbf{1 4 4}$ 319-329.

32 St-Jean E, Blain F \& Comtois R. High prolactin levels may be missed by immunoradiometric assay in patients with macroprolactinomas. Clinical Endocrinology (Oxford) 199644 305-309.

33 Grottoli S, Razzore P, Gaia D, Gasperi M, Giusti M, Colao A, Ciccarelli E, Gasco V, Martino E, Ghigo E \& Camanni F. Threehour spontaneous $\mathrm{GH}$ secretion profile is as reliable as oral glucose tolerance test for the diagnosis of acromegaly. Journal of Endocrinological Investigation 200326 123-127.

34 Arnaldi G, Angeli A, Atkinson AB, Bertagna X, Cavagnini F, Chrousos GP, Fava GA, Findling JW, Gaillard RC, Grossman AB, Kola B, Lacroix A, Mancini T, Mantero F, Newell-Price J, Nieman LK, Sonino N, Vance ML, Giustina A \& Boscaro M. Diagnosis and complications of Cushing's syndrome: a consensus statement. Journal of Clinical Endocrinology and Metabolism 2003 88 5593-5602.

35 Ghigo E, Aimaretti G, Corneli G, Bellone J, Arvat E, Maccario M \& Camanni F. Diagnosis of GH deficiency in adults. Growth Hormone and IGF-I Research $1998 \mathbf{8}$ S55-S58.

36 Abs R. Update on the diagnosis of GH deficiency in adults. European Journal of Endocrinology 2003148 S3-S8.

37 Ferretti E, Persani L, Jaffrain-Rea ML, Giambona S, Tamburrano G \& Beck-Peccoz P. Evaluation of the adequacy of levothyroxine replacement therapy in patients with central hypothyroidism. Journal of Clinical Endocrinology and Metabolism $1999 \mathbf{8 4}$ 924-929.

38 Wartofsky L \& Burman KD. Alterations in thyroid function in patients with systemic illness: the 'euthyroid sick syndrome'. Endocrine Reviews 19823 164-217.

39 Mariotti S, Franceschi C, Cossarizza A \& Pinchera A. The aging thyroid. Endocrine Reviews 199516 686-715.

40 Maghnie M, Uga E, Temporini F, Di Iorgi N, Secco A, Tinelli C, Papalia A, Casini MR \& Loche S. Evaluation of adrenal function in patients with growth hormone deficiency and hypothalamicpituitary disorders: comparison between insulin-induced hypoglycemia, low-dose ACTH, standard ACTH and CRH stimulation tests. European Journal of Endocrinology 2005152 735-741.

41 Valenti G. Adrenopause: an imbalance between dehydroepiandrostenedione (DHEAS) and cortisol secretion. Journal of Endocrinological Investigation 200225 (10 Suppl) 29-35.

42 American Society of Anesthesiologists, New classification of physical status. Anesthesiology 196324111.

43 Ciric I, Ragin A, Baumgartner C \& Pierce D. Complications of transsphenoidal surgery: result of a national survey, review of the literature and personal experience. Neurosurgery $1997 \mathbf{4 0}$ 225-237.

44 Barker FG, Klibanski A \& Swearingen B. Transsphenoidal surgery for pituitary tumors in the United States 1996-2000: mortality, morbidity, and the effects of hospital and surgeon volume. Journal of Clinical Endocrinology and Metabolism $2003 \mathbf{8 8} 4709-4719$.

45 Cappabianca P \& De Divitiis E. Endoscopy and transsphenoidal surgery. Neurosurgery 200454 1043-1048.

46 Arafah BM. Reversible hypopituitarism in patients with large nonfunctioning pituitary adenomas. Journal of Clinical Endocrinology and Metabolism $1986 \mathbf{6 2} 1173-1179$.

47 Bradley KM, Adams CB, Potter CP, Wheeler DW, Anslow PJ \& Burke CW. An audit of selected patients with non-functioning pituitary adenoma treated by transsphenoidal surgery without irradiation. Clinical Endocrinology (Oxford) 199441 655-659. 
48 Lillehei KO, Kirschman DL, Kleinschmidt-DeMasters BK \& Ridgway EC. Reassessment of the role of radiation therapy in the treatment of endocrine-inactive pituitary macroadenomas. Neurosurgery $1998 \mathbf{4 3} 432-438$.

49 Woollons AC, Hunn MK, Rajapakse YR, Hamilton DA, Conaglen JV \& Balakrishnan V. Non-functioning pituitary adenomas: indications for postoperative radiotherapy. Clinical Endocrinology (Oxford) 200053 713-717.

50 Turner HE, Stratton IM, Byrne JV, Adams CB \& Wass JA. Audit of selected patients with nonfunctioning pituitary adenomas treated without irradiation - a follow-up study. Clinical Endocrinology (Oxford) $1999 \mathbf{5 1} 281-284$.

51 Feldkamp J, Santen R, Harms E, Aulich A, Modder U \& Scherbaum WA. Incidentally discovered pituitary lesions: high frequency of macroadenomas and hormone-secreting adenomas-results of a prospective study. Clinical Endocrinology (Oxford) 199951 109-113.

52 Giustina A, Barkan A, Casanueva FF, Cavagnini F, Frohman L, Ho K, Veldhuis J, Wass J, Von Werder K \& Melmed S. Criteria for cure of acromegaly: a consensus statement. Journal of Clinical Endocrinology and Metabolism 200085 526-529.

53 Seidman PA, Kofke WA, Policare R \& Young M. Anesthetic complications of acromegaly. British Journal of Anaesthesia $2000 \mathbf{8 4}$ 179-182.

54 Ben-Shlomo A \& Melmed S. The role of pharmacotherpay in perioperative management of patients with acromegaly. Journal of Clinical Endocrinology and Metabolism 2003 88 963-968.

55 Colao A, Ferone D, Cappabianca P, Del Basso De Caro ML, Marzullo P, Monticelli A, Alfieri A, Merola B, Cali A, de Divitiis E \& Lombardi G. Effect of octreotide pretreatment on surgical outcome in acromegaly. Journal of Clinical Endocrinology and Metabolism 199782 3308-3314.

56 Bochicchio D, Losa M Buchfelder M \& the European Cushing's Disease Survey Study Group, Factors influencing the immediate and late outcome of Cushing's disease treated by transsphenoidal surgery: a retrospective study by the European Cushing's Disease Survey Group. Journal of Clinical Endocrinology and Metabolism $1995803114-3120$.

57 Liu JK \& Couldwell WT. Contemporary management of prolactinomas. Neurosurgical Focus 200416 E2.

58 Molitch ME, Thorner MO \& Wilson CB. Management of prolactinomas: overview and introduction. Journal of Clinical Endocrinology and Metabolism 199782 996-1000.

59 Karunakaran S, Page RC \& Wass JA. The effect of menopause on prolactin levels in patients with hyperprolactinemia. Clinical Endocrinology (Oxford) $20015 \mathbf{5 4} 295-300$.

60 Baldelli R, Ferretti E, Jaffrain-Rea ML, Minniti G, Iacobellis G, Gulino A \& Tamburano G. Cardiac effects of SR-Lanreotide, a slow-release somatostatin analog, in acromegalic patients. Journal of Clinical Endocrinology and Metabolism 199984 527-532.

61 Amato G, Mazziotti G, Rotondi M, Iorio S, Doga M, Sorvillo F, Manganella G, Di Salle F, Giustina A \& Carella C. Long-term effects of lanreotide SR and octreotide LAR on tumour shrinkage and GH hypersecretion in patients with previously untreated acromegaly. Clinical Endocrinology (Oxford) 200256 65-71.

62 Freda PU. How effective are current therapies for acromegaly? Growth Hormone \& IGF Research 200313 S144-S151.

63 Van der Lely AJ, Harris AG \& Lamberts SWJ. The sensitivity of growth hormone secretion to medical treatment in acromegalic patients: Influence of age and sex. Clinical Endocrinology (Oxford) $199237181-185$.

64 Didoni G, Grottoli S, Gasco V, Battistini M, Ferone D, Giusti M, Ragazzoni F, Ruffo P, Ghigo E \& Minuto F. Cost-of-illness study in acromegalic patients in Italy. Journal of Endocrinological Investigation 200427 1034-1039.

65 Baldelli R, Battista C, Leonetti F, Ghiggi MR, Ribaudo MC, Paoloni A, D'Amico E, Ferretti E, Baratta R, Liuzzi A, Trischitta V \& Tamburrano G. Glucose homeostasis in acromegaly: effects of long-acting somatostatin analogues treatment. Clinical Endocrinology (Oxford) $200359492-499$.
66 Clayton RN. Cardiovascular function in acromegaly. Endocrine Reviews $200324272-277$.

67 Petrossians P, Borges-Martin L, Espinoza C, Daly A, Betea D, Valdes Socin H, Stevenaert A, Chanson P \& Beckers A. Gross total resection or debulking of pituitary adenomas improves hormonal control of acromegaly by somatostatin analogs. European Journal of Endocrinology 2005152 61-66.

68 Trainer PJ. Lessons from 6 years of GH receptor antagonist therapy for acromegaly. Journal of Endocrinological Investigation 200326 (Suppl 10) 44-52.

69 Heaney AP. Novel medical approaches for the treatment of Cushing's disease. Journal of Endocrinological Investigation 200427 $591-595$.

70 van Schaardenburg D, Roelfsema F, van Seters AP \& Vielvoye GJ. Bromocriptine therapy for non-functioning pituitary adenoma. Clinical Endocrinology (Oxford) $198930475-484$.

71 Gasperi M, Petrini L, Pilosu R, Nardi M, Marcello A, Mastio F, Bartalena L \& Martino E. Octreotide treatment does not affect the size of most non-functioning pituitary adenomas. Journal of Endocrinological Investigation $199316541-543$.

72 Andersen M, Bjerre P, Schroder HD, Edal A, Hoilund-Carlsen PF, Pedersen $\mathrm{PH} \&$ Hagen $\mathrm{C}$. In vivo secretory potential and the effect of combination therapy with octreotide and cabergoline in patients with clinically non-functioning pituitary adenomas. Clinical Endocrinology (Oxford) $20015423-30$.

73 Laurberg P, Andersen S, Bulow Pedersen I \& Carle A. Hypothyroidism in the elderly: pathophysiology, diagnosis and treatment. Drugs Aging 200522 23-38.

74 Whitehead MI. Royal College of Obstetricians and Gynaecologists study group on menopause and HRT. RCOG, Recommendations on hormone replacement therapy. Lancet 2005365749.

75 American Society for Reproductive Medicine (ASRM), Practice Committee. Treatment of androgen deficiency in the aging male. Fertility and Sterility 200481 1437-1440.

76 Snyder PJ. Hypogonadism in elderly men - what to do until evidence comes. New England Journal of Medicine $20043 \mathbf{3 0 0}$ 440-442.

77 Feldt-Rasmussen U, Wilton P Jonsson P \& KIMS Study Group \& KIMS International Board, Aspects of growth hormone deficiency and replacement in elderly hypopituitary adults. Growth Hormone $\mathcal{E}$ IGF Research 200414 S51-S58.

78 Monson JP \& Jonsson P. Aspects of growth hormone (GH) replacement in elderly patients with GH deficiency: data from KIMS. Hormone Research 200060 S112-S120.

79 Jerome J, Shiry L \& Leyland-Jones B. Deregulation of the IGF-I axis in cancer: epidemiological evidence and potential therapeutic interventions. Endocrine-Related Cancer $200310561-578$.

80 Colao A, Di Somma C, Spiezia S, Filipella M, Pivonello R \& Lombardi G. Effect of growth hormone $(\mathrm{GH})$ and/or testosterone replacement on the prostate in $\mathrm{GH}$-deficient adult patients. Journal of Clinical Endocrinology and Metabolism $2003 \mathbf{8 8} 88$-94.

81 Brada M, Rajan B, Traish D, Ashley S, Holmes-Sellors PJ, Nussey S \& Uttley D. The long-term efficacy of conservative surgery and radiotherapy in the control of pituitary adenomas. Clinical Endocrinology (Oxford) $199338571-578$.

82 Barrande G, Pittino-Lungo M, Coste J, Ponvert D, Bertagna X, Luton JP \& Bertherat J. Hormonal and metabolic effects of radiotherapy in acromegaly: long-term results in 128 patients followed in a single center. Journal of Clinical Endocrinology and Metabolism $2000853779-3785$.

83 Minniti G, Jaffrain-Rea ML, Osti M, Esposito V, Santoro A, Solda F, Gargiulo P, Tamburrano G \& Enrici RM. The long-term efficacy of conventional radiotherapy in patients with $\mathrm{GH}$-secreting pituitary adenomas. Clinical Endocrinology (Oxford) 200562 210-216.

84 Brada M, Ashley S, Ford D, Traish D, Burchell L \& Rajan B. Cerebrovascular mortality in patients with pituitary adenoma. Clinical Endocrinology (Oxford) 200257 713-717.

85 Erfurth EM, Bulow B, Svahn-Tapper G, Norrving B, Odh K, Mikoczy Z, Bjork J \& Hagmar L. Risk factors for cerebrovascular deaths in patients operated and irradiated for pituitary tumors. 
Journal of Clinical Endocrinology and Metabolism $2002 \quad 87$ $4892-4899$.

86 Estrada J, Boronat M, Mielgo M, Magallon R, Millan I, Diez S, Lucas T \& Barcelo B. The long-term outcome of pituitary irradiation after unsuccessful transsphenoidal surgery in Cushing's disease. New England Journal of Medicine 1997336 $172-177$.

87 Brada M, Ajithkumar TV \& Minniti G. Radiosurgery for pituitary adenomas. Clinical Endocrinology (Oxford) 200461 $531-543$.
88 Jalali R, Brada M, Perks JR, Warrington AP, Traish D, Burchelle L, McNair H, Thomas DGT, Robinson S \& Johnston DG. Stereotactic conformal radiotherapy for pituitary adenomas: technique and preliminary experience. Clinical Endocrinology (Oxford) 200052 695-702.

Received 23 May 2005

Accepted 1 September 2005 